Article

\title{
Ecology of Gamebirds in Namha National Protected Area, Lao People's Democratic Republic
}

\author{
William V. Bleisch ${ }^{1}$ D , Paul Buzzard ${ }^{1,2}$, Deang Souliya ${ }^{1}$, Xueyou Li $^{3}$ and Daniel M. Brooks ${ }^{4, *(\mathbb{D})}$ \\ 1 China Exploration and Research Society, Hong Kong, China; billbleisch@cers.org.hk (W.V.B.); \\ p_buzzard@yahoo.com (P.B.); souliya1989@hotmail.com (D.S.) \\ 2 The Nature Conservancy, Dublin, OH 43017, USA \\ 3 Kunming Institute of Zoology, Chinese Academy of Sciences, Kunming 650201, China; xueyouli@126.com \\ 4 Department of Vertebrate Zoology, Houston Museum of Natural Science, Houston, TX 77030, USA \\ * Correspondence: dbrooks@hmns.org
}

check for updates

Citation: Bleisch, W.V.; Buzzard, P.; Souliya, D.; Li, X.; Brooks, D.M. Ecology of Gamebirds in Namha National Protected Area, Lao People's Democratic Republic. Birds 2021, 2, 445-459. https://doi.org/ 10.3390/birds2040033

Academic Editor: Jukka Jokimäki

Received: 27 October 2021

Accepted: 3 December 2021

Published: 8 December 2021

Publisher's Note: MDPI stays neutral with regard to jurisdictional claims in published maps and institutional affiliations.

Copyright: (c) 2021 by the authors Licensee MDPI, Basel, Switzerland. This article is an open access article distributed under the terms and conditions of the Creative Commons Attribution (CC BY) license (https:/ / creativecommons.org/licenses/by/ $4.0 /)$.
Simple Summary: A limited amount of work has been done on gamebirds in Lao PDR, primarily comprising wildlife bio-inventories, which include several species of gamebirds. Using camera-trap data, we describe the general biology and ecology of several species of gamebirds and assess species status in Namha National Protected Area in Luang Namtha Province, Laos. Three species of Hill Partridges were detected in low numbers. Three species of pheasants were active during daylight hours. There are slightly more females than males in local populations of Silver and Gray Peacock Pheasants. Occupancy for Silver Pheasant and Gray Peacock Pheasant is higher in rougher terrain, while it is lower near trekking trails for Red Junglefowl. In situations where our findings are not new, we compare and contrast our results with other studies. This is the first time that detailed research focusing on gamebirds has been done on-the-ground in Lao PDR. This information is vital for management guidelines, and to set forth conservation recommendations.

Abstract: Using camera-trap data, we describe the ecology and occupancy of several species of gamebirds while assessing associations at Namha National Protected Area (Lao People's Democratic Republic). We detected three species of Arborophila Partridges, albeit in low numbers. Red Junglefowl Gallus gallus show typical diurnal activity, and we provide a record of a male-female pair commensally associated with a boar Sus scrofa. Silver Pheasants Lophura nycthemera have sex ratios slightly favoring females, and are mostly solitary; we provide novel findings of male age structure and rectrix molt. Gray Peacock Pheasants Polyplectron bicalcaratum sex ratios also favor females; males are recorded displaying as early as late February, while daily activity is somewhat bimodal, and we provide novel findings of male age structure. Analysis of the association between occupancy and 14 environmental covariates indicated that Silver Pheasant and Gray Peacock-Pheasant were associated with rougher terrain, and Red Junglefowl had higher occupancy far from well-groomed trails used for tourism. We discuss our results by comparing and contrasting our findings with other studies, and consider implications for conservation in the region.

Keywords: Arborophila; conservation; Gallus gallus; galliformes; gamebird; Lao PDR; Lophura nycthemera; partridge; pheasant; Polyplectron bicalcaratum; sympatry; tropical

\section{Introduction}

Gamebirds (order Galliformes) play an important role in maintaining the integrity of the forests in which they live, cultivating plant community structure through seed predation dynamics, and tilling the soil routinely [1]. Moreover, they are often a vital protein source for people and predatory wildlife alike [2]. However, owing to their desirability as a protein source, gamebirds are often characterized by unsustainable harvest, not only for protein, but also for the feather and live bird markets [3]. These trends, along with the wholesale 
destruction of the habitats they thrive in, have led to many species of gamebirds being threatened with extinction (e.g., [4,5]).

The Birdlife International Redlist records 15 species of gamebirds as present in Lao People's Democratic Republic (PDR hereafter), 3 of them stable and the other 12 decreasing $[6,7]$. A limited amount of work has been done on gamebirds in Lao PDR, primarily comprising wildlife bio-inventories, which include reports of several species of gamebirds. These include Xe Bang Nouan National Protected Area (NPA, south-central Lao PDR) [8] and Nam Et-Phou Louey NPA (northern Lao PDR) [9,10]. Johnson et al. [9] camera-trapped 35 species of mammals and birds, including five species of gamebirds, and concluded that the relative abundance of small prey animals (such as gamebirds) was significantly higher where human density was low. Rasphone et al. [10] camera-trapped 43 species and estimated the probabilities of occupancy, persistence, colonization and detection, including three species of pheasants and Rufous-throated Partridge. Additionally, Brickle et al. [4] reviewed the Indochinese range (Lao PDR, Cambodia and Vietnam), habitat and conservation status of 21 species of gamebirds to assess the overall conservation requirements, with non-functional protected areas as the primary threat. Previous surveys recorded the presence of six species of gamebirds in and around the Namha NPA: Mountain Bamboo Partridge Bubusicola fytchii, Rufous-throated Partridge Arborophila rufogularis, Barbacked Partridge A. brunneopectus, Red Junglefowl Gallus gallus, Silver Pheasant Lophura nycthemera and Gray Peacock Pheasant Polyplectron bicalcaratum [11,12].

For many species of gamebirds, it is extremely challenging to study intimate aspects of life history and ecology due to their shy, retiring nature. A major advantage of camera-traps is they can be used successfully in remote regions to help fill in large information gaps for cryptic birds that are difficult to observe [13]. The studies of Savini and Sukumal [14] and Sailo [15], while being notable contributions for Silver Pheasant Lophura nycthemera and Gray Peacock Pheasant Polyplectron bicalcaratum, respectively, did not utilize cameratrapping in their methodologies. We were fortunate to opportune datasets for both of these species, thanks to the utilization of camera trap images that were bycatch from general diversity surveys [16].

Relatively few in-depth autoecological (species-level) studies have been undertaken for the species comprising the focus of our work. Our objectives herein are to add to knowledge of the general biology and ecology of several species of gamebirds (i.e., Arborophila partridges and pheasants) and assess species associations in Namha National Protected Area (NNPA hereafter) in Luang Namtha Province, Lao PDR. While NNPA contains valuable habitat for the gamebirds studied here and other species of wildlife, there are growing threats to the continued persistence of these species. Understanding their ecology, behavior and status could inform conservation management and improve their prospects for survival. We discuss our results by comparing and contrasting our findings with other studies, and consider implications for conservation in the region.

\section{Materials and Methods}

\subsection{Study Site}

All cameras were set in or adjacent to NNPA, which protects $2224 \mathrm{~km}^{2}$ of habitat located between $20^{\circ} 33^{\prime}-21^{\circ} 15^{\prime} \mathrm{N}$ Latitude and $101^{\circ} 7^{\prime}-101^{\circ} 37^{\prime}$ E Longitude, ranging from 540-2094 $\mathrm{m}$ asl (Figure 1). The region receives an average of $1482 \mathrm{~mm}$ of rainfall each year and has a seasonal climate with a clear rainy season (April-September, peak in August). Monthly average temperature varies, with monthly lows of $11^{\circ} \mathrm{C}$ in January to monthly highs $>32^{\circ} \mathrm{C}$ in May and June. Habitats in NNPA include secondary and old-growth mixed deciduous and evergreen forest, including semi- and moist evergreen forest $[12,17,18]$. 


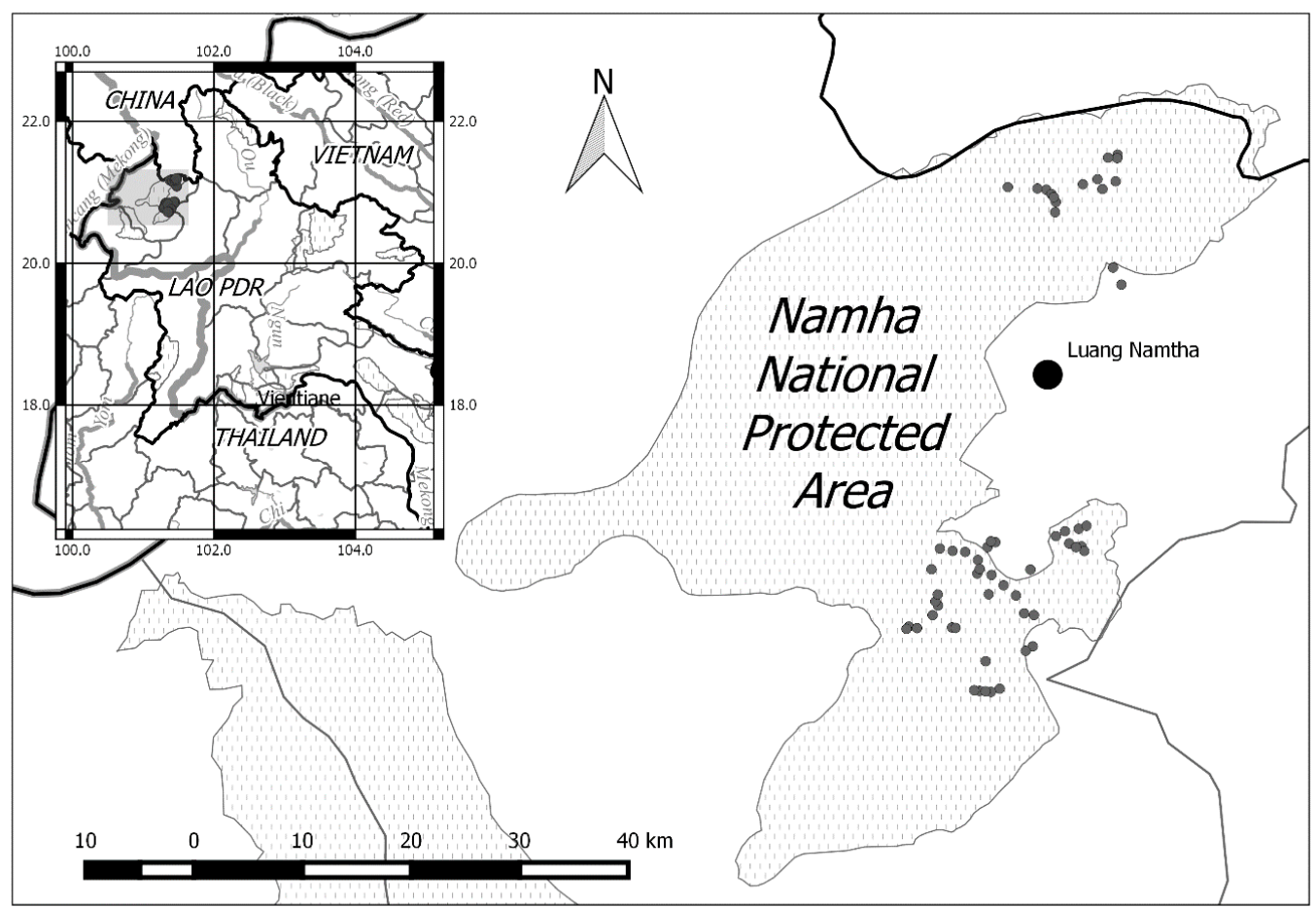

Figure 1. Location of Namha NPA in Luang Namtha Province (Lao PDR) and the locations of camera traps (solid circles). Inset: Location of Luang Namtha Province in northern Lao PDR in relation to Thailand (to the west), Myanmar (to the northwest) and China (to the north). The two large dots in the inset represent our camera-trapping areas.

Potential predators of birds and eggs that were confirmed as present with camera trapping included (in decreasing order of camera trap events): crab-eating mongoose Herpestes urva, dhole Cuon alpinus, leopard cat Prionailurus bengalensis, Asiatic golden cat Pardofelis temminckii, golden jackal Canis aureus and, rarely, clouded leopard Neofelis nebulosi, large-toothed ferret-badger Melogale personata, hog badger Arctonyx collaris, marbled cat P. marmorata and yellow-throated marten Martes flavigula. Aside from humans, northern pig-tailed macaque Macaca leonina was the most commonly observed primate [16].

Guided nature tourism on designated trails occurred during the study, especially during the drier winter season. In 2016, an estimated 4700-6000 visitors entered Nam Ha NPA for trekking, camping and kayaking [19]. Hunting for personal use of non-protected species (i.e., species not listed as Lao Category I) was also allowed outside of the Totally Protected Zone of NNPA [2,17]. Hunting with bird lime, deadfall traps, snares, simple muskets and modern guns was common throughout the study area all year-round. While hunting of most species for subsistence is legal in the Controlled Use Zone of NNPA, there is also considerable illegal sale of all sizes of birds in local markets [16]. NNPA is surrounded by villages, with several inside the protected area. Habitat near villages is affected by harvest of timber, fuel wood and edible and medicinal plants. Most villages practice swidden farming on steep slopes, creating a mosaic of open habitats and young secondary forests, and recently, some forest inside NNPA was converted to rubber plantations. Due to the large size of NNPA, two sizable refuges are designated as Totally Protected Zones to harbor sensitive species. Management improvements since 2018 have focused on patrols and monitoring in these zones.

\subsection{Camera Trapping}

Remotely triggered camera traps with infrared flash (Bushnell Trailcam and Aggressor Lo-glow models) were set at 81 locations during two sessions (53 initially set between 6 April 2013-12 June 2015, and 28 initially set between 7 May 2017-28 September 2018). 
Locations were chosen by the investigators and local guides based on a clear field of view, evidence of wildlife activity and indigenous knowledge of wildlife habits. Cameras were strapped to tree trunks at a height of approximately $1 \mathrm{~m}$ above ground level (we note that this height may not be optimal for capture of smaller birds). Cameras at 18 locations malfunctioned or were stolen; the remaining 63 cameras ( 42 and 21 from respective trapping sessions) were set in evergreen broad-leaf forest between 551-1371 m asl (Figure 1, Supplementary File S1).

All pictures from the remaining 63 cameras were screened for the presence of animals, and images were sorted using an access-based database template (WWF-Malaysia Tiger Conservation Project Camera Trap Database ver. 261112). Gamebirds were identified to species level and confirmed following Robson [20]. Captures were considered independent if they were separated by $\geq 1 \mathrm{~h}$ without captures of the same species. The number of independent capture events and captures/trap night were tallied for each species at each location.

Based on the camera trap location acquired by GPS, abiotic parameters were calculated from data in public sources (Supplementary File S1). Distance to the nearest village was estimated from known coordinates of villages or coordinates available through GaiaGPS Version 2020.10 (GaiaGPS.com accessed on 15 March 2021). Distance to the nearest tourism location was estimated from digital maps of trekking trails created from our records of GPS tracks. The percentage of forest cover was collected from a single MODIS Terra MOD44B Vegetation Continuous Field (VCF), acquired from 6 March 2014-5 March 2015 [21]. MODIS images provide an estimate of percent vegetation cover around coordinate points calculated from $500 \mathrm{~m}$ resolution surface reflectance data. Normalized difference vegetation index (ndvi), an index of vegetation density, was calculated from stacked pairs of cloud-free Landsat 8 multiband images acquired in 2018. Elevation (checked against ground-truthed altimeter data), aspect, slope, topographic position index (TPI), terrain roughness index (TRI) and roughness [22] were determined using a pair of Aster Digital Elevation Maps (ASTGTMV003) covering the study site, using rgdal and GIS in R [23] with standard procedures. The mid-point for each camera's trapping session was projected onto sine and cosine transformations of calendar dates to produce two covariate parameters, dryseason and orthogonal rainseason, such that dryseason peaked on 15 April, while rainseason peaked on 15 July, near the peak of the average monthly rainfall.

\subsection{Statistical Methods and Occupancy Modeling}

For modeling, events were further grouped in longer occasions of seven days and the dataset was reduced to only those images from 48 camera stations separated by at least $700 \mathrm{~m}$ to ensure independence. A multispecies hierarchical analysis of occupancy and detectability was carried out using the approach of RN hierarchical models [24-27]. Briefly, this involves modeling capture of a species at any given camera trap station as the result of a two-state process - an individual of the species must be active in the area of the camera station and must then be detected by the camera. The model derives a species-specific estimate of the number of individuals or groups of individuals that use the area around the station and, thus, that are available for capture (with mean value $\lambda$, which we interpret to be the result of a complex process related to both abundance and use of space [28]), and of the probability of the camera trap detecting that individual or group $(r$, which we interpret as a function of both the camera's ability to detect the animals and the activity of the animals). The model can then be used to estimate occupancy at each station. Incidentally, expected occupancy of species $i$ at site $j, \widehat{\psi_{i j}}$, is directly related to $\lambda_{i j}$ in the model, since:

$$
\widehat{\psi_{i j}}=1-\exp \left(-\lambda_{i j}\right)
$$

Both $\lambda_{i j}$ and $r_{i j}$ may depend on one or more environmental covariates at the trap site. Thus:

$$
\log \left(\lambda_{i j}\right)=u_{i}+\beta_{0} \times \mathrm{ENV}_{j}+\beta_{i} \times \mathrm{EN} V_{j}
$$


The betas here are vectors of species invariant community-wide coefficients $\left(\beta_{0}\right)$ and species-specific coefficients $\left(\beta_{i}\right)$ for the response to environmental covariates in matrix ENV. Similarly:

$$
\operatorname{logit}\left(r_{i j}\right)=v_{i}+\gamma_{0} \times \mathrm{DE}_{j}+\gamma_{i} \times \mathrm{DE} T_{j}
$$

where $\gamma_{0}$ and $\gamma_{i}$ are vectors of coefficients for the response to the covariates in matrix DET, for the species invariant community parameters and species-specific parameters, respectively.

Data were collated, transformed and analyzed in software $R$ ( $R$ version 4.0.2 [22 June 2020] [23]) with an RStudio interface. For modeling, we assumed closure within each of the two trapping sessions and independence between trap-stations $>700 \mathrm{~m}$ apart. Both of these assumptions should be considered first approximations likely to have been violated, especially for long-lived and wide-ranging species [29], but perhaps not for these three species. Models were fit with Gibbs Sampling in a Bayesian framework using R-JAGS via the R2Jags package [30,31]. Bayesian credible intervals (BCI), 95\% highest probability density intervals (HPDI) and Bayesian posterior predicted probabilities (Bppp) were calculated from simulations in R. Beta coefficients were considered significant if the Bppp was less than the Holm-Bonferroni criterion for multiple tests [32]. Details and R scripts are included in Supplementary File S1.

\section{Results}

\subsection{Camera Trap Captures}

Between 6 April 2013-3 October 2015 (4003 trap days/nights), 5533 images representing 996 separate captures of wildlife were collected from 31 sampling stations in NNPA (first session). Following initial analyses, data from an additional set of 22 traps active between 7 May 2017-16 February 2019 (second session) were collated, adding an additional 4788 images from 488 captures (1947 trap days/nights). In sum, 10,321 images representing 1484 independent captures of wildlife were collected during 5950 trap days/nights of sampling.

A total of 31 species of birds were detected (Table S1), including six species of gamebirds (Table 1), which are highlighted in the species accounts below. A rarefaction curve [33] (Figure S1) shows an exponentially slowing growth in the accumulation of gamebird species over the 5950 days of sampling.

Table 1. Six species of gamebirds recorded from 63 camera traps (April 2013-June 2015 and May 2017-September 2018, Supplementary Files S2 and S3) in Namha NPA, Luang Namtha Province, Lao PDR.

\begin{tabular}{ccc}
\hline Common Name & Latin Name & \# Events \\
\hline Rufous-throated Partridge & Arborophila rufogularis & 1 \\
Bar-backed Partridge & Arborophila brunneopectus & 5 \\
Scaly-breasted Partridge & Arborophila chloropus & 4 \\
Red Junglefowl & Gallus gallus & 21 \\
Silver Pheasant & Lophura nycthemera & 84 \\
Gray Peacock Pheasant & Polyplectron bicalcaratum & 44 \\
\hline
\end{tabular}




\subsection{Partridges}

For Rufous-throated Partridge (Arborophila rufogularis), only two birds, an adult with an approximately $75 \%$ grown subadult, were photo-trapped at $545 \mathrm{~m}$ asl with $68 \%$ forest cover, $2.49 \mathrm{~km}$ from the nearest village. This occurred at midday for $30 \mathrm{~min}$ on 25 May 2018.

Bar-backed Partridge (Arborophila brunneopectus) was another rarely recorded species of partridge, recorded during five independent events (Table 1) at the same site, $694 \mathrm{~m}$ asl with $80 \%$ forest cover, $3.2 \mathrm{~km}$ from the nearest village. Five solitary individuals (e.g., Figure 2A) were recorded at ca. 09:00 $(n=2)$ and 11:00-15:35 $(n=3), 8-13$ March and 8 April 2014.

(A)

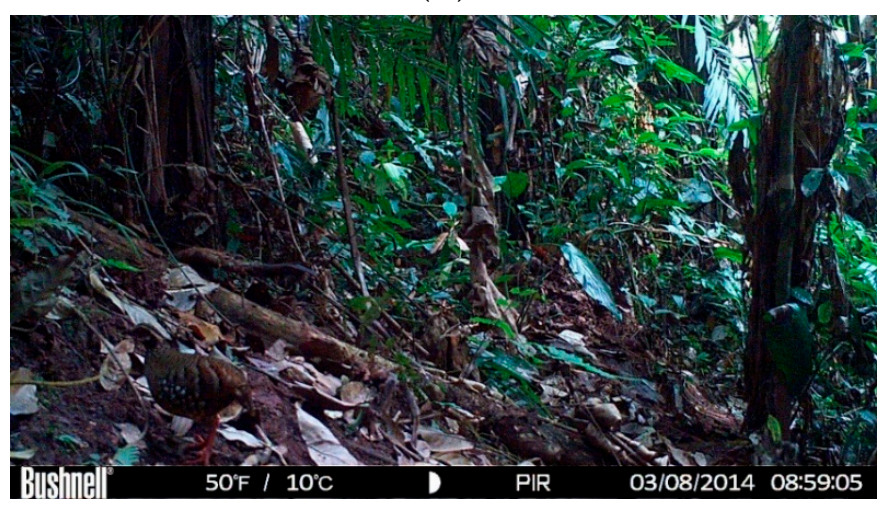

(B)

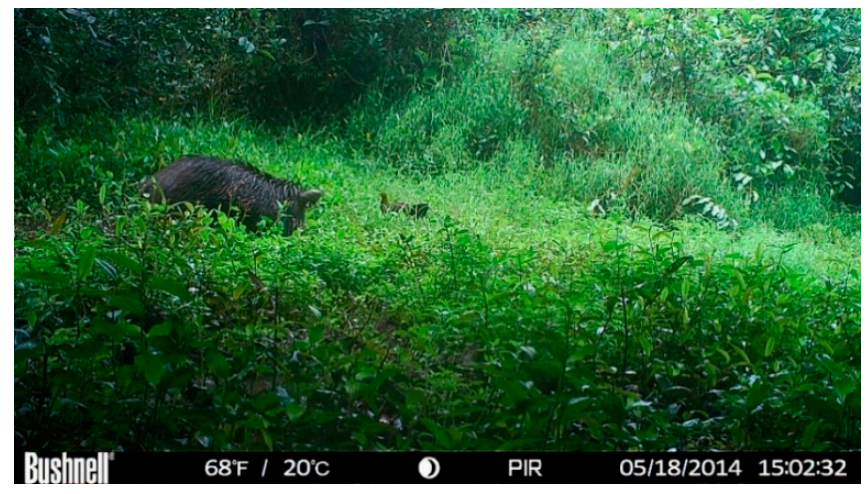

(C)

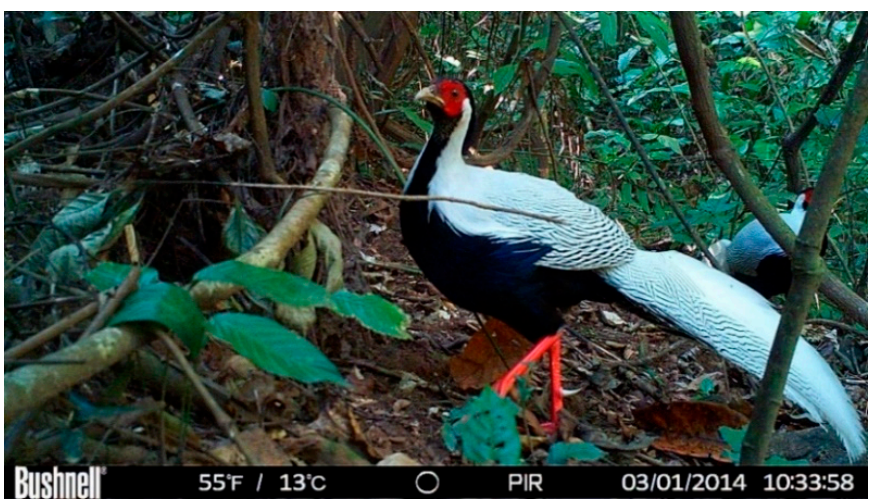

(D)

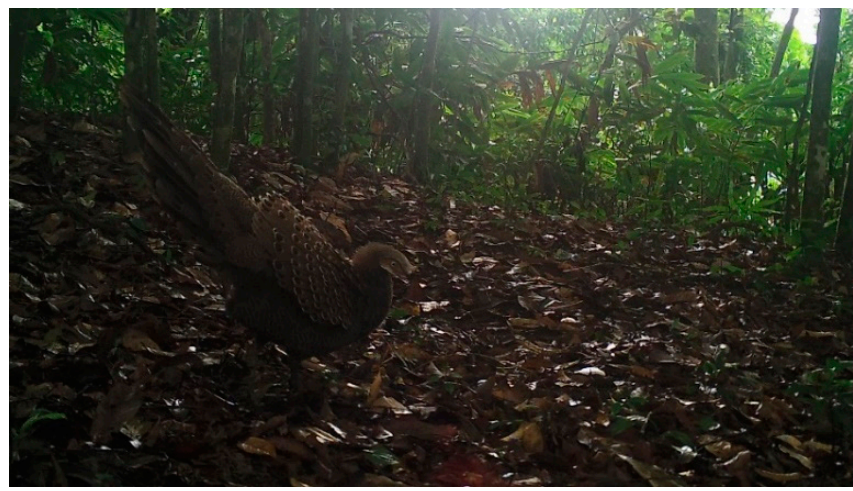

Figure 2. Photographs from camera-traps in Namha NPA: (A) Bar-backed Partridge Arborophila brunneopectus, (B) female Red Junglefowl Gallus gallus commensally associated with a boar Sus scrofa, (C) male Silver Pheasants Lophura nycthemera forming part of a group, (D) male Gray Peacock Pheasant Polyplectron bicalcaratum approaching full vertical display.

Scaly-breasted Partridge (Arborophila chloropus), the third rarely recorded congener, had four independent events (Table 1) at three different sites, averaging $612 \mathrm{~m}$ asl (range $=545-694)$ with $76 \%$ forest cover (range $=68-80), 3.38 \mathrm{~km}$ from the nearest village (range $=2.49-4.45)$. Four solitary individuals were recorded primarily during crepuscular periods (06:25 [n=2], 14:40-18:25 [n=2]) spanning 16 April-26 May. 


\subsection{Red Junglefowl (Gallus gallus)}

This species was recorded in 21 independent events (Table 1) at 10 different sites, averaging $777 \mathrm{~m}$ asl (range $=551-1011)$ with $75 \%$ forest cover (range $=65-80), 4.15 \mathrm{~km}$ from the nearest village (range $=1.34-7.28$ ).

Twelve solitary individuals ( 6 males, 6 females) and a male-female pair (1:1 sex ratio) were present at camera-traps, primarily $\leq 1 \mathrm{~min}(n=17)$, also for 2, 5, 13 and $24 \mathrm{~min}$ ( $n=1$ each). There was an increase in detections towards late morning, rising to a peak just after midday (Figure 3). Mean occupancy indicated that this species was probably available for capture at less than two-thirds of the camera-trap stations (mean $=41.9 \%$, HPDI 14.6-68.6\%; Table S2). Mean predicted individual detectability ( $r$, the probability of detecting an available bird within any given seven-day occasion) was 3.91\% (HPDI $0.004-12.00 \%$; Table S2).

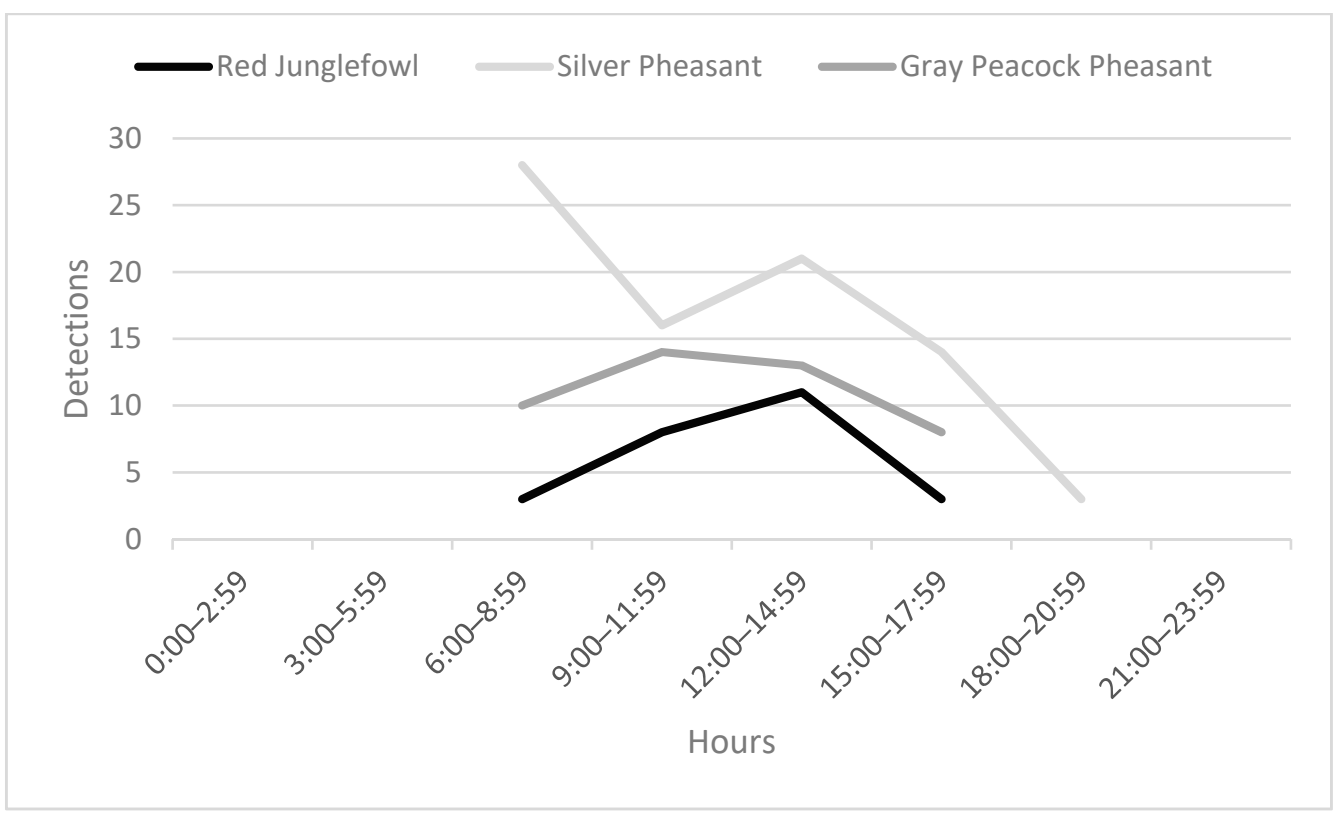

Figure 3. Activity patterns of Red Junglefowl Gallus gallus, Silver Pheasant Lophura nycthemera and Gray Peacock Pheasant Polyplectron bicalcaratum at Namha NPA, Luang Namtha Province (Lao PDR).

On 18 May 2014 at 15:02 a male-female pair of Red Junglefowl was observed associated with a boar Sus scrofa (Figure 2B), probably commensally eating arthropod prey displaced by the foraging boar. 


\subsection{Silver Pheasant (Lophura nycthemera)}

This was the most frequently recorded species in this study, with 84 independent events (Table 1 ) at 25 different sites, averaging $837 \mathrm{~m}$ asl (range $=545-1277$ ) with $76 \%$ forest cover (range $=65-81), 4.51 \mathrm{~km}$ from the nearest village (range $=1.10-11.32)$.

The sex ratio was 1:1.13 (53 males, 60 females; $X^{2}=0.319, p=0.572$ ), including 13 yearling males (mid-May-mid-November) that comprised $24.5 \%$ of the male population (adult vs. yearling males: $X^{2}=12.76, p=0.0003$ ). Age-sex groups varied extensively, with $75.6 \%$ solitary birds (solitary vs. groups; $X^{2}=25.0, p=0.00001$ ) making up the majority (25 males, 32 females, 5 yearling males). Other age-sex classes (e.g., Figure 2C) included primarily adult male-female pairs $(n=5)$, with yearling males $(n=2)$; single adult males with two $(n=3)$ or three $(n=3)$ adult females; two adult males with a single female $(n=1)$ or three adult males with two females $(n=1)$; two females $(n=3)$ or a single female with two yearling males $(n=2)$ and two yearling males $(n=2)$. Two males were growing new tail rectrices post-molt in mid-August.

Durations at camera-traps were primarily $\leq 1 \min (n=70)$, also $2-10(n=6), 11-25$ $(n=8)$ and $41-120(n=3)$ min. Activity was bimodal, exploding at $06: 00$, then gradually diminishing until a second peak just after midday, until ceasing at 19:00 (Figure 3). Occupancy was estimated to be the highest of all six species of gamebirds, indicating that this species was present at over one-third of the trap stations (mean 60.8\%, HPDI 40.8$85.7 \%$, Table S2). Mean predicted individual detectability (r) was $6.48 \%$ (HPDI $0.88-12.30 \%$, Table S2).

\subsection{Gray Peacock Pheasant (Polyplectron bicalcaratum)}

This second most commonly detected gamebird in the study had 44 independent events (Table 1) at nine different sites, averaging $816 \mathrm{~m}$ asl (range $=545-1010)$ with $76 \%$ forest cover (range $=68-80), 4.43 \mathrm{~km}$ from the nearest village (range $=2.29-7.51$ ).

The sex ratio was 1:1.21 ( 19 males, 23 females; $X^{2}=0.381, p=0.537$, NS), including three yearling males (mid-March-late April; adult vs. yearling males: $X^{2}=7.6, p=0.005$ ) that comprised $15.7 \%$ of the male population. All individuals were solitary with the exception of three males actively displaying (e.g., Figure 2D) to females (late February-mid-June; solitary vs. pairs; $X^{2}=26.3, p=0.00001$ ).

Durations at camera-traps were primarily $\leq 1 \min (n=45)$, also $3-4(n=26)$ and $18-20$ $(n=2)$ min. Activity generally began around 07:00, and was somewhat bimodal, peaking mid-morning and again slightly less in mid-afternoon before terminating prior to 18:00 (Figure 3). Occupancy was relatively low compared to the other two species of pheasants, indicating that this species was probably present at less than one-half of the trap stations (mean 28.7\%, HPDI $12.2-55.1 \%$, Table S2). Mean predicted individual detectability (r) was 7.68\% (HPDI 0.05-19.22\%, Table S2).

\subsection{Species Associations}

In addition to the aforementioned pair of Red Junglefowl commensally following a boar, several temporal species associations were anecdotally noted between gamebird species. Of the six species in this study, all but Scaly-breasted Partridge were occasionally photographed by the same camera within $1 \mathrm{~h}$ of each other (mean $=23 \mathrm{~min}$, range $=3-60 \mathrm{~min}, n=8$; Table 2 ).

The primary species within these temporally proximal associations include Silver Pheasant (present in $75 \%$ of records, $n=6)$ and Gray Peacock Pheasant $(63 \%, n=5)$. In the case of Red Junglefowl both associations were males, whereas $60 \%(n=3)$ of the associations were males for Gray Peacock Pheasant, and 33\% contained males for Silver Pheasant $(n=2)$.

All cases involved solitary adults, except for a parent-offspring group of Rufous-throated Partridge associated with an adult pair of Silver Pheasants. The majority $(75 \%, n=6)$ of these associations took place during breeding season (March-April), and many $(63 \%, n=5)$ of the records were from a single camera trap (NH22) in March-April 2014 (Table 2). 
Table 2. Temporally proximal associations among Rufous-throated Partridge (RtP), Bar-backed Partridge (BbP), Scaly-breasted Partridge (SbP), Red Junglefowl (RJf), Silver Pheasant (SPh) and Gray Peacock Pheasant (GPP).

\begin{tabular}{|c|c|c|c|c|c|c|c|c|}
\hline Date & Trap \# & RtP & $\mathrm{BbP}$ & $\mathrm{SbP}$ & RJf & $\mathrm{SPh}$ & GPP & Time Lag (min) \\
\hline 8 March 2014 & $\mathrm{NH} 22$ & & $x$ & & M & & & 12 \\
\hline 8 April 2014 & $\mathrm{NH} 22$ & & $x$ & & & & $\mathrm{M}$ & 4 \\
\hline 19 April 2014 & $\mathrm{NH} 22$ & & & & & $\mathrm{~F}$ & $\mathrm{~F}$ & 19 \\
\hline 20 May 2014 & $\mathrm{NH} 22$ & & & & & M & M & 7 \\
\hline 27 May 2014 & $\mathrm{NH} 22$ & & & & & $\mathrm{~F}$ & M & 40 \\
\hline 24 September 2014 & $\mathrm{NH} 22 \mathrm{~b}$ & & & & & $\mathrm{~F}$ & $\mathrm{~F}$ & 60 \\
\hline 25 May 2018 & NR12 & $X x$ & & & & $\mathrm{MF}$ & & 40 \\
\hline 10 November 2018 & NR30 & & & & M & $\mathrm{F}$ & & 3 \\
\hline
\end{tabular}

$\mathrm{M}=$ male, $\mathrm{F}=$ female, $\mathrm{X}=$ sex undetermined, $\mathrm{x}=$ sub-adult.

\subsection{Environmental Associations with Occupancy}

In preliminary models with 12-14 covariates, we found that the covariate factors camera model and wide-angle setting and the continuous covariates aspect and vegetation (ndvi) showed no significant association with individual detectability (Table S3).

We found no significant differences in estimated availability $(\lambda)$ from the first and second trapping sessions and no significant effect of season or percentage of forest cover on occupancy of any species in this sample of camera stations (Table S3).

Examining a model with only the six most influential covariates (distance to nearest village, distance to nearest tourism trail, altitude as a quadratic, terrain roughness, ndvi and aspect as a complex variable), both Silver Pheasant (SP) and Gray Peacock Pheasant (GPP) showed significantly higher estimated lambda at camera stations in rougher terrain. (Table 3, Tables S4 and S5; for SP, median estimated coefficient of association $\widehat{\beta_{i j}}=0.538$, mean 0.536 [95\% HPDI 0.089-0.975], Bppp [Bayesian posterior predicted $p$ of absolute value > 0] = 0.010; for GPP, median 1.576, mean 1.691 [0.139-3.535], Bppp = 0.004, respectively). We found no significant effect of elevation on any species, although Gray Peacock Pheasant was significantly less associated with mid-elevations (Table 3, Tables S4 and S5, median -3.505 , mean -3.980 [-9.183-0.184], Bppp $=0.008$ ). Silver Pheasant availability tended to increase with increasing distance to the nearest village (median 0.473 , mean $0.474[-0.016-0.958]$ Bppp $=0.029)$. Red Junglefowl was significantly associated with sites far from trails used for nature tourism (median 1.726, mean 2.263 [ -0.077 to 6.457] Bppp $=0.004)$.

Table 3. Posterior predicted coefficients of association with environmental covariates for Red Junglefowl (RJf), Silver Pheasant (SPh) and Gray Peacock Pheasant (GPP). Selected means of species-specific coefficients of association $\left(\hat{\beta_{i j}}\right)$, SD, 95\% Highest Probability Density Interval (HPDI) and Bayesian posterior predicted probability (Bppp) of greater or less than 0.0 from a Royle Nichols hierarchical model of availability and detectability. Six covariates (eight coefficients) were included in the model, with only those associations with Bppp $<0.1$ shown here (see Supplementary File S4 Table S4 for all combinations). ${ }^{*}$ indicates significant at aggregate $p<0.05$ by the Holm-Bonferroni correction for multiple tests [32]. See Supplementary File S1 for detailed methods and R code.

\begin{tabular}{|c|c|c|c|c|c|c|c|c|}
\hline \multirow[b]{2}{*}{ Species } & \multirow[b]{2}{*}{ Covariate } & \multirow[b]{2}{*}{ Mean } & \multirow[b]{2}{*}{ SD } & \multirow[b]{2}{*}{ Median } & \multicolumn{2}{|c|}{ 95\% HPDI } & \multirow[b]{2}{*}{ Bppp } & \\
\hline & & & & & lower & Upper & & \\
\hline RJf & altitude & -0.733 & 0.669 & -0.629 & -2.063 & 0.356 & 0.088 & \\
\hline GPP & altitude.squared & -3.980 & 2.685 & -3.505 & -9.183 & 0.184 & 0.008 & * \\
\hline $\mathrm{SPh}$ & log.roughness & 0.536 & 0.227 & 0.538 & 0.089 & 0.975 & 0.010 & * \\
\hline GPP & log.roughness & 1.691 & 0.904 & 1.576 & 0.139 & 3.535 & 0.004 & * \\
\hline RJf & log distance to tourism & 2.263 & 1.810 & 1.726 & -0.077 & 6.457 & 0.004 & * \\
\hline $\mathrm{SPh}$ & log distance to tourism & 0.365 & 0.287 & 0.356 & -0.204 & 0.923 & 0.097 & \\
\hline GPP & log distance to tourism & 0.798 & 0.665 & 0.725 & -0.425 & 2.173 & 0.090 & \\
\hline $\mathrm{SPh}$ & distance to village & 0.474 & 0.249 & 0.473 & -0.016 & 0.958 & 0.029 & \\
\hline
\end{tabular}




\section{Discussion}

\subsection{Species Detection and Occupancy}

Several extremely shy species (Table 1) that might have otherwise gone undetected were documented with camera-traps (cf. [34]). Gamebirds, especially pheasants, are often shy due to hunting, and therefore, they are under-accounted for in avifaunal inventories [5] The camera-traps were set to detect species using lower strata of the forest, with eight primarily terrestrial species of birds recorded (the six gamebirds of this study as well as Rusty-naped Pitta (Hydrornis oatesi) and White's Thrush (Zootheria aurea); Table S1).

Of the six species of gamebirds detected, all were assessed by IUCN as Least Concern with Decreasing Populations [7], but none are endemic and all have a broad geographic distribution [35]. Silver Pheasant and Gray Peacock-Pheasant are on the list of Category 1 Protected Species in Lao PDR. Despite their reclusive nature, we are fairly confident that we detected all species of extant pheasants in the region, as they accounted for $53 \%$ ( $n=159)$ of the 297 total avian detections made (Table S1). Moreover, these three species of pheasants were the only three accounted for by Johnson et al. [9] and Rasphone et al. [10] in northern Lao PDR, as well as in extensive market surveys [16], appearing in the same order of relative detection as in our camera trapping study.

The smaller partridges were more rarely detected; whether this is a consequence of their smaller size not triggering the camera-traps or their relative rarity is uncertain. Of the 31 detected species of birds represented, the majority were only detected on one or two occasions (Table S1). In light of the few partridge detections $(n=10$ events total, range $=1-5$ events/sp.), it is likely that they were either too small to trigger the camera traps, or rare in the region relative to pheasants. That virtually no partridge were found during eight years of market surveys [16], despite other species of small birds being common, supports the idea that partridge are indeed rare and seldom encountered.

We did not obtain any records of Japanese Quail (Coturnix japonica), Blue-breasted Quail (Synoicus chinensis), Chinese Francolin (Francolinus pintadeanus), Mountain Bamboo Partridge or Green Peafowl (Pavo muticus), all of which geographically overlapped the region of our study site on range maps (e.g., [7]). These five species were not expected, as they all occupy more open habitats, including grassland, scrub, swamp and open woodland, and in some cases at higher altitudes [35] than our camera traps were located.

\subsection{Occupancy Estimates}

Occupancy estimates for the three species of pheasants are available for another large tropical forest site in northern Lao PDR, Nam Et Phou Louey NPA [10]. While methods were not identical, comparison showing occupancy 2.3 (Silver Pheasant) to 4.1 (Red Junglefowl) times higher at our site suggests that gamebirds may be more common at NNPA. Future work could address possible reasons for this, including differences in hunting intensity, in habitat or in abundance of predators.

\subsection{Arborophila Partridges}

Owing to the aforementioned rarity of this guild, little information was gleaned about their biology. All were found in forest with cover ranging $68-80 \%$, and $\geq 2.5 \mathrm{~km}$ from the nearest village. This suggests that they may not tolerate human disturbance (cf. [35]).

Judging by the age (ca. 6 weeks) of the Rufous-throated Partridge chick, it can be assumed that it hatched in mid-April. This is within the typical range of breeding dates (February-July) provided by Madge et al. [35].

The Bar-backed Partridge was observed most often from morning through midday, whereas the Scaly-breasted Partridge was observed most often during crepuscular periods. While this information is apparently novel, numbers of observations were too limited to draw firm conclusions. While other studies have examined niche partitioning in Arborophila partridges (e.g., [36,37]), the focus was on habitat separation rather than temporal asynchrony of circadian activity patterns (e.g., [38]). Whether there could be a form of temporal niche allocation is unknown, but it certainly warrants further study. 


\subsection{Red Junglefowl (Gallus gallus)}

We found junglefowl begin their activity post-dawn, then were moderately active until a sharp peak post-midday, followed by lower activity levels, until detections fell to zero by 18:00 (Figure 3). This is similar to what was reported by Johnsgard [1], where the species is active from dawn until around 09:00, then resting midday until becoming active again from mid-afternoon until dark.

The behavior of Red Junglefowl following large ungulates to consume displaced arthropods has been observed in association with several species in Thailand, including gaur Bos gaurus [39], sambar Rusa unicolor (Kelvin Lim unpubl. data) and boar (Marcus Chua unpubl. data). Our preliminary observation of the boar association reported here is apparently the first published record involving this commensalism outside of Thailand.

\subsection{Silver Pheasant (Lophura nycthemera)}

The sex ratio found in our study in Lao PDR was 1:1.13, which is mostly similar to sex ratios found in other studies. In central Thailand, the sex ratio averaged 1:1.6 over 5 months; however, the ratio during a given month changed between January (1:1.3) when there were more females, to May (1:0.7), when there were slightly more males [14]). In Guangdong Province, China, the sex ratio varied depending upon the habitat substrate, that is 1:1 in dry soil and 1:3 in low grassland [40].

The observation that yearling males (recorded mid-May-mid-November) comprised one-fourth of the male population is apparently a novel record of age-class distribution for this species, as are records of males growing new tail rectrices in mid-August. The description of age-class ratios are important data to help build life history tables to estimate population growth. Molt is relevant species biology information for sound management decisions (i.e., when individuals are most vulnerable). More detailed study is warranted on age structure and molt in Silver Pheasant populations.

Our findings of $75 \%$ of all records as solitary birds was not shared by others. Johnsgard [1] considered the species to travel mostly in groups. For example, Savini and Sukumal [14] found mean group size to range from 3.0-4.1 between January and May, but no results were reported outside of these months. Perhaps these differences can be attributed to these authors focusing strictly on social groups rather than incorporating solitary individuals into their datasets.

We recorded constant diurnal activity with bimodal peaks, albeit diminishing until complete termination by 19:00. Similarly, Beebe [41] observed a general bimodal trend, active early morning and late afternoon, while completely ceasing activity during midday. Differing from both of these studies, in Guangdong Province, China, activity was fairly constant between 07:00-18:00, although it slightly diminished during mid-morning [42]. While the starting and ending times were similar, the pattern in China was unimodal (more constant) rather than bimodal, as seen previously [41] and here.

\subsection{Gray Peacock Pheasant (Polyplectron bicalcaratum)}

The sex ratio of peacock pheasants in our study was 1:1.21. In contrast, males were more abundant at two wildlife sanctuaries in Mizoram state, India: more than two-fold at Lengteng (2.47:1), and less dramatically at Tawi (1.29:1). These differences can perhaps be explained by bias, with auditory counts (calls performed only by males) being incorporated into the data collection methods by Sailo [15].

The three yearling males recorded (mid-March-late April) comprising $15.7 \%$ of the male population is apparently a new estimate of age-class for this species. Nonetheless, more detailed work on age structure is needed within Gray Peacock Pheasant populations.

We recorded three male peacock pheasants actively displaying between late February and mid-June. This is only slightly earlier than the typical estimate of the breeding season beginning in March (through June) for this species (cf. [35]).

Activity at our site generally begins around 07:00, and is somewhat bimodal, peaking mid-morning and again slightly less in mid-afternoon before terminating before 18:00 
(Figure 3). In Arunachal Pradesh, India, this species was active much earlier (03:00-11:00), peaking from 06:00-08:00 [43]. While the overall times, as well as durations in Lao PDR $(11 \mathrm{~h})$ versus India $(8 \mathrm{~h})$ were different, activity still occurred around dawn in both studies.

\subsection{Species Associations}

With the exception of Scaly-breasted Partridge, the remaining five species in this study were occasionally photographed by the same camera $\leq 1 \mathrm{~h}$ of each other, with the primary species being Silver Pheasant and Gray Peacock Pheasant (Table 2). In order to be considered a temporal association, the two species should be associated non-randomly not just in space but in time. For example, considering only events at camera trap station NR30, the probability that Red Junglefowl was randomly captured within $1 \mathrm{~h}$ before or after the three events of Silver Pheasant capture can be estimated as $p=0.004$. The probability that Rufous-throated Partridge was randomly captured within $1 \mathrm{~h}$ of one of the five events of other gamebird capture at camera trap station NR12 was $p=0.008$. For Bar-backed Partridge at NH22, where it was captured five times, the probability was $p=0.19$.

In addition to multiple associations noted by Beebe [41], there have been other noted species associations, including Arborophila Partridges in Cambodia [37], Arborophila and Tropicoperdix Partridges in Viet Nam [44], and Siamese Fireback L. diardi and Silver Pheasant in Thailand [14]. Temporal species associations provide a metric of resource allocation, and ultimately insight of competition or coexistence within a given community. However, these studies are traditionally employed for mammal communities, especially carnivores (e.g., [45,46]), rather than gamebirds (e.g., [38]), especially gamebird communities in the Eastern Hemisphere. Nonetheless, such studies could prove fruitful if a fertile study site for such dynamics can be located. For example, nearly two-thirds of the records for the associations in Table 2 came from a single camera-trap (NH22), primarily during the breeding season (March-April); thus, there was a narrow window of opportunity. Incidentally, NH22 was a special site, representing lowland forest proximal to a stream with large trees, rich understory and probably deep soil.

\subsection{Environmental Associations}

Both Gray Peacock Pheasant and Silver Pheasant occupancy was significantly associated with rougher terrain, while Red Junglefowl showed a slight tendency to be associated with lower elevations in this sample (Table 3). Terrain roughness is measured as the largest difference in elevation between the target grid cell and adjacent grid cells, roughly isomorphic with slope [22]. The results suggest that, in NNPA, Silver Pheasant and Gray Peacock Pheasant may favor steep slopes, while Red Junglefowl is less fastidious.

We found that Red Junglefowl showed significantly less occupancy near well-groomed trails used for trekking tourism. Silver Pheasant and Gray Peacock Pheasant showed a slight tendency for this as well (Table 3). Silver Pheasant also showed a tendency for lower occupancy near villages. Red Junglefowl may be particularly easy to hunt because of its obvious call, which can be heard from a long distance, and hence, it may be especially vulnerable near well-traveled routes. Alternatively, this species may simply be more wary than others and avoid areas with regular human presence.

\subsection{Conservation}

While the presence of three sympatric species of partridges inside NNPA is encouraging for the future of these species, the low number of detections as well as the relatively low occupancy of all gamebirds is worrying and probably reflects intensive hunting, especially near accessible trails and villages. Partridges in particular are poorly studied in the region. While assumed to be of Least Concern, their low rates of detection found here suggest that they may be rarer than often assumed. Yu et al. [36] suggested that the Bar-backed Partridge, with its restricted distribution, small population and low ecological adaptability, might be the most vulnerable gamebird species in the karst forests of Guangxi. Arborophila Partridges might, thus, be particularly vulnerable to hunting or habitat degra- 
dation. Patrolling, enforcement and behavioral change campaigns are needed to ensure that hunting is within sustainable limits, and is excluded from the Totally Protected Zone of NNPA. Over-hunting of vulnerable species can be further reduced by strictly controlling illegal sales of wildlife, and by campaigns to change attitudes and behaviors of sellers and consumers.

Other threats also need to be addressed to better protect the habitat of these species. Rubber plantations support few birds, and while swidden landscapes may be suitable for some avian species, they are not for those that depend on undisturbed old-growth forests. As climate change continues and accelerates, catastrophic crown fires in the dry season present an increasing threat to habitat, and this should be addressed with fire prevention and suppression, and reduction in greenhouse gas emissions. Conservation management efforts should be supported with uninterrupted funding and political backing to ensure the protection and restoration of natural habitat, continuous monitoring, thorough removal of snares and successful prosecution of repeat offenders apprehended by the newly formed patrol teams.

\section{Conclusions}

Camera-trapping records from a general survey provided useful data for study of six species of gamebirds, including three species of partridges that are rarely observed and have been under-studied in the region. While the dataset was small for partridges, in part because cameras were not placed to optimize capture of these species, the data were sufficient to suggest some specific conclusions about their ecology, occurrence and potential threats to their survival. Future studies might be able to avoid problems of small numbers of detection by setting more cameras closer to the ground (e.g., $35 \mathrm{~cm}$ ) and farther apart in space (700 $\mathrm{m}$ or more between cameras). Simulations might then be able to address questions of temporal associations, and avoidance, between species. This could be particularly valuable for partridges, which are little-studied and perhaps rarer than assumed. Researchers should consider the value of "data-mining" other general camera trap surveys even if not optimized for the study of gamebirds. The results of such efforts will add to the body of information about these and other little-studied terrestrial birds, increasing understanding of their ecology and supporting efforts for their conservation.

Supplementary Materials: The following will be available online at https: / www.mdpi.com/article / 10.3390/birds2040033/s1, Supplementary File S1: Additional methods as R scripts. Supplementary File S2: Events of camera trap capture data (one-hour criterion). Supplementary File S3: Covariate data. Supplementary File S4: Additional figure and tables.

Author Contributions: W.V.B. and P.B. administered funding and logistics for the fieldwork. Most of the fieldwork was carried out by P.B. and D.S., with contributions by W.V.B., X.L. led the Remote Sensing and Digital Elevation Maps analysis and provided key direction and R scripts for modeling. D.M.B. conceived and wrote the first draft of the ms, along with specific sections written by W.V.B. and X.L. All authors have read and agreed to the published version of the manuscript.

Funding: We would like to thank the donors and patrons of the China Exploration and Research Society (CERS) of Hong Kong and its president Howman Wong for funding this work, and in particular, we thank the Loke Wan Tho and Lady Yuen Peng McNeice Charitable Foundations for their generous and consistent support since 2013.

Institutional Review Board Statement: The study was conducted according to the guidelines of the WMA Declaration of Helsinki, and approved by the Ethics Committee of China Exploration \& Research Society (2013).

Informed Consent Statement: Not applicable.

Data Availability Statement: Data will be available as supplementary files once the manuscript has been accepted. 


\begin{abstract}
Acknowledgments: Airkhun Khamvongxay, Ladasone Phompunya, Franzi Weiser and William Ruzek provided key assistance reviewing and cataloguing camera trap images, and they and many staff from Luang Namtha Provincial Tourism Bureau and Tourism Police, the Namha NPA and the Luang Namtha Tour Guide Group assisted us in the field. We also thank the Luang Namtha Provincial Department of Information, Culture and Tourism and the NNPA Management for their support. We thank three anonymous reviewers and the editors for helpful comments and questions which greatly improved the manuscript. We also thank Marcus Chua and Kelvin Lim for providing unpublished information on Red Junglefowl associated with various ungulates.
\end{abstract}

Conflicts of Interest: The authors declared no potential conflict of interest with respect to the research, authorship and/or publication of this article.

\title{
References
}

1. Johnsgard, P.A. Pheasants of the World: Biology and Natural History; Smithsonian Institutions Press: Washington, DC, USA, 1999.

2. Johnson, A.A.H.; Krahn, J.; Wijerathna, D.; Bank, A.D. Linking Sustainable Harvest of Managed Wildlife and Household Food Consumption in the Nam Et-Phou Louey National Protected Area; PDR: Vientiane, Laos, 2012.

3. Fuller, R.A.; Garson, P.J. Pheasants: Status Survey and Conservation Action Plan 2000-2004; IUCN: Gland, Switzerland, 2000.

4. Brickle, N.W.; Duckworth, J.W.; Tordoff, A.W.; Poole, C.M.; Timmins, R.; McGowan, P.J.K. The status and conservation of Galliformes in Cambodia, Laos and Vietnam. Biodiv. Cons. 2008, 17, 1393-1427. [CrossRef]

5. Brooks, D.M.; Buzzard, P.J.; Li, X.; Bleisch, W.V. Galliforme diversity in southwestern Yunnan, with notes on Ithaginis cruentus and Crossoptilon crossoptilon biology. Bull. Br. Ornithol. Club 2019, 139, 206-215. [CrossRef]

6. Birdlife_International Datazone: Lao Bird Species List. Available online: http://datazone.birdlife.org/species/results?fam=0\& gen $=0 \&$ cty $=116$ (accessed on 30 September 2021).

7. Birdlife_International IUCN Red List for Birds. Available online: http:/ / www.birdlife.org (accessed on 30 September 2021).

8. Timmins, R.J.; Bleisch, W.V. A Wildife and Habitat Survey of Xe Bang Nouan National Biodiversity Conservation Area, Savannakhet and Salavan Provinces, Lao PDR; PDR: Vientiane, Laos, 1995.

9. Johnson, A.; Vongkhamheng, C.; Hedemark, M.; Saithongdam, T. Effects of human-carnivore conflict on tiger (Panthera tigris) and prey populations in Lao PDR. Anim. Conserv. 2006, 9, 421-430. [CrossRef]

10. Rasphone, A.; Kéry, M.; Kamler, J.F.; Macdonald, D.W. Documenting the demise of tiger and leopard, and the status of other carnivores and prey, in Lao PDR's most prized protected area: Nam Et-Phou Louey. Glob. Ecol. Conserv. 2019, 20, e00766. [CrossRef]

11. Duckworth, J.W.; Salter, R.E.; Khounboline, K. Wildlife in Lao PDR: 1999 Status Report; PDR: Vientiane, Laos, 1999.

12. Johnson, A.; Singh, S.; Dongdala, M.; Vongsa, O. Wildlife Hunting and Use in the Nam Ha National Protected Area: Implications for Rural Livelihoods and Biodiversity Conservation; Wildlife Conservation Society: Vientiane, Laos, 2003.

13. O'Brien, T.G.; Kinnaird, M.F.; Wibisono, H.T. Crouching tigers, hidden prey: Sumatran tiger and prey populations in a tropical forest landscape. Anim. Conserv. 2003, 6, 131-139. [CrossRef]

14. Savini, T.; Sukumal, N. Group structure and reproductive behaviour of Siamese fireback Lophura diardi and silver pheasant Lophura nycthemera at Khao Yai National Park, Thailand. Int. J. Gall. Conserv. 2009, 1, 12-17.

15. Sailo, L. Ecological Studies on Grey Peacock Pheasant Polyplectron bicalcaratum (Linn, 1758) in the Tropical Forest of Mizoram, India. Ph.D. Thesis, Mizoram University, Aizawl, India, 2019.

16. Bleisch, W.V.; Souliya, D. Protection for a Neglected Wildlife Sanctuary on China's Southern Border; PDR: Luang Namtha, Laos, 2015.

17. Berkmuller, K.; Evans, T.; Timmins, R.; Vongphet, V. Recent advances in nature conservation in Lao PDR. Oryx 1995, 29, 253-260. [CrossRef]

18. Tizard, R.; Davidson, P.; Khounboline, K.; Salivong, K. A Wildlife and Habitat Survey of Nam Ha and Nam Kong Protected Areas, Louang Namtha Province, Lao PDR; Wildlife Conservation Society: Vientiane, Laos, 1997.

19. Eshoo, P. Integrated Conservation of Biodiversity and Forests Project (ICBF)_Financial Cooperation: Improving the Link between Ecotourism E Conservation in Nam Ha National Protected Area, Luang Namtha Province; GFA Consulting Group: Hamburg, Germany, 2017.

20. Robson, C. Birds of South-East Asia; Princeton: Princeton, NJ, USA, 2005.

21. Dimiceli, C.; Carroll, M.; Sohlberg, R.; Kim, D.H.; Kelly, M.; Townshend, J.R.G. MOD44B MODIS/Terra Vegetation Continuous Fields Yearly L3 Global 250 m SIN Grid V006. Available online: https:/ / lpdaac.usgs.gov/products/mod44bv006/\#tools (accessed on 9 June 2021).

22. Wilson, M.F.J.; Connell, B.O.; Guinan, J.C.; Grehan, A.J. Multiscale terrain analysis of multibeam bathymetry data for habitat mapping on the continental slope. Mar. Geod. 2007, 30, 3-35. [CrossRef]

23. R Core Team. R: A Language and Environment for Statistical Computing; R Foundation for Statistical Computing: Vienna, Austria, 2020.

24. Royle, J.A.; Nichols, J.D. Estimating abundance from repeated presence-absence data or point counts. Ecology 2003, 84, 777-790. [CrossRef]

25. Tobler, M.W.; Hartley, A.Z.; Carrillo-percastegui, S.E.; Powell, G.V.N. Spatiotemporal hierarchical modelling of species richness and occupancy using camera trap data. J. Appl. Ecol. 2015, 52, 413-421. [CrossRef] 
26. Rich, L.N.; Miller, D.A.W.; Robinson, H.S.; McNutt, J.W.; Kelly, M.J. Using camera trapping and hierarchical occupancy modelling to evaluate the spatial ecology of an African mammal community. J. Appl. Ecol. 2016, 53, 1225-1235. [CrossRef]

27. Li, X.; Bleisch, W.V.; Jiang, X. Using large spatial scale camera trap data and hierarchical occupancy models to evaluate species richness and occupancy of rare and elusive wildlife communities in southwest China. Divers. Distrib. 2018, 24, 1560-1572. [CrossRef]

28. Broadley, K.; Burton, A.C.; Avgar, T.; Boutin, S. Density-dependent space use affects interpretation of camera trap detection rates. Ecol. Evol. 2019, 9, 14031-14041. [CrossRef]

29. Rogan, M.S.; Balme, G.A.; Distiller, G.; Pitman, R.T.; Broadfield, J.; Mann, G.K.H.; Whittington-Jones, G.M.; Thomas, L.H.; O'Riain, M.J. The influence of movement on the occupancy-density relationship at small spatial scales. Ecosphere 2019, 10, e02807. [CrossRef]

30. Plummer, M. JAGS: A Program for Analysis of Bayesian Graphical Models Using Gibbs Sampling. Available online: http: / / citeseer.ist.psu.edu/plummer03jags.html.\%0AG (accessed on 22 June 2020).

31. Su, Y.-S.; Yajima, M. Package ‘R2jags' Version 0.6-1. Available online: https://cran.r-project.org/web/packages/R2jags/R2jags. pdf (accessed on 15 November 2021).

32. Holm, S. A simple sequentially rejective multiple test procedure. Scand. J. Stat. 1979, 6, 65-70.

33. Rovero, F.; Martin, E.; Rosa, M.; Ahumada, J.A.; Spitale, D. Estimating species richness and modelling habitat preferences of tropical forest mammals from camera trap data. PLoS ONE 2014, 9, e103300. [CrossRef]

34. Forrester, T.; O’Brien, T.; Fegraus, E.; Jansen, P.; Palmer, J.; Kays, R.; Ahumada, J.; Stern, B.; McShea, W. An open standard for camera trap data. Biodivers. Data J. 2016, 4, e10197. [CrossRef] [PubMed]

35. Madge, S.; McGowan, P.J.K.; Kirwan, G.M. Pheasants, Partridges and Grouse; Christopher Helm: London, UK, 2002.

36. Yu, C.-X.; Yang, G.; Li, D.; Zhou, F. Ecological distribution and spatial niche of pheasants in the Karst mountains of southwest Guangxi Province, China. Zool. Res. 2011, 32, 549-555.

37. Chhin, S.; Souter, N.J.; Ngoprasert, D.; Browne, S.J.; Savini, T. Spatial interactions between sympatric partridges in the Cardamom Mountains, Southwest Cambodia. Raffles Bull. Zool. 2020, 68, 308-318.

38. Brooks, D.M.; Pando-Vasquez, L.; Ocmin-Petit, A. Resource separation in a Napo-Amazonian gamebird community. In Biology and Conservation of Cracids in the New Millennium; Brooks, D.M., Gonzalez, F.F., Eds.; Miscellaneous Publications of The Houston Museum of Natural Science: Houston, TX, USA, 2001; pp. 213-225.

39. Olgilvie, C.S. The behavior of seladang. Malay Nat. J. 1954, 9, 1-10.

40. Xiao, S.-J. Influence of sex ratio on habitat selection of Lophura nycthemera in non-breeding period. J. Anhui Agric. Soc. 2011, 39, 2813-2816.

41. Beebe, W. Pheasants: Their Lives and Homes; Doubleday, Doran and Co.: New York, NY, USA, 1936.

42. Chen, L.; Shu, Z.; Xiao, Z. Application of camera-trapping data to study daily activity patterns of Galliformes in Guangdong Chebaling National Nature Reserve. Biodivers. Sci. 2019, 27, 266-272.

43. Selvan, K.M.; Lyngdoh, S.; Veeraswami, G.G.; Habib, B. An assessment of abundance, habitat use and activity patterns of three sympatric pheasants in an eastern Himalayan lowland tropical forest of Arunachal Pradesh, India. Asian J. Conserv. Biol. 2013, 2, 52-60.

44. Vy, N.T.; Ngoprasert, D.; Gale, G.A.; Brown, S.J.; Savini, T. Co-occurrence of two sympatric galliform species on a landscape-scale. Raffles Bull. Zool. 2017, 65, 60-67.

45. Hearn, A.J.; Cushman, S.A.; Ross, J.; Goossens, B.; Hunter, L.T.B.; Macdonald, D.W. Spatio-temporal ecology of sympatric felids on Borneo: Evidence for resource partitioning? PLoS ONE 2018, 13, e0200828. [CrossRef] [PubMed]

46. Mukherjee, S.; Singh, P.; Silva, A.P.; Ri, C.; Kakati, K.; Borah, B.; Tapi, T.; Kadur, S.; Choudhary, P.; Srikant, S.; et al. Activity patterns of the small and medium felid (Mammalia: Carnivora: Felidae) guild in northeastern India. J. Threat. Taxa 2019, 11, 13432-13447. [CrossRef] 